\title{
Andrzej Franciszek Dziuba, biskup towicki. Jedyny Bóg. Z nauczania pasterskiego 2013-2014 \\ Wydawnictwo Uniwersytetu Kardynała Stefana Wyszyńskiego, Warszawa 2015, 336 s.
}

Zobowiązanie zadane Kościołowi w jego posłudze ewangelizacyjnej wybrzmiewa szczególnie wyraźnie w słowach Jezusa Chrystusa: „Idźcie więc i nauczajcie wszystkie narody” (Mt 28, 19). Idźcie więc i czyńcie uczniów ze wszystkich narodów. To zadanie, w mocach Ducha Świętego, nieustannie podejmuje Kościól, a zwłaszcza specjalnie przeznaczeni do tej posługi, tj. prezbiterzy i biskupi. Oto w Wydawnictwie Uniwersytetu Kardynała Stefana Wyszyńskiego w Warszawie ukazał się wybór takiego nauczania Andrzeja F. Dziuby.

Autor jest biskupem łowickim i profesorem teologii moralnej na Uniwersytecie Kardynała Stefana Wyszyńskiego w Warszawie, gdzie kieruje Katedrą Historii Teologii Moralnej. Jest autor wielu artykułów, szkiców, opracowań i książek, np. Matka Boża z Guadalupe (Katowice 2005), Rodzina $w$ dialogu $z$ Bogiem $w$ nauczaniu Ojca Świętego Jana Pawta II. Zarys problematyki (Warszawa 2006), Jezus nam przebacza. Przygotowanie do sakramentu pojednania (Warszawa 2009), Stużyć życiu (Niepokalanów 2012), Perspektywy i wyzwania chrześcijaństwa (Pelplin 2014).

Książkę otwiera Spis treści (s. 5-14) oraz Stowo wstępne (s. 15-16). Następnie zamieszczono, w układzie chronologicznym, 65 homilii. Każda z nich opatrzona jest tytułem oraz informacjami o miejscu i dacie wygłoszenia. Zazwyczaj podano także okoliczności wygłoszenia. 
Reports and reviews
Wszystkie teksty kaznodziejskie mają także wskazania odnośnie do czytań biblijnych, które proklamowane były podczas danej celebracji.

Zbiór inauguruje homilia Patriae et Ecclesiae commodis serviens podczas Mszy św. w intencji zmarłego kard. Józefa Glempa, Prymasa Polski, wygłoszona w bazylice katedralnej w Łowiczu, dnia 27.01.2013 (s. 17-23). Natomiast zamyka homilia Dziś się narodzit Chrystus Pan, Zbawiciel wygłoszona podczas Mszy św. pasterskiej także w bazylice katedralnej w Łowiczu (s. 333-336).

Na terenie diecezji łowickiej autor głosił słowo Boże m.in. w Łowiczu, Nowym Mieście nad Pilicą, Skierniewicach, Kutnie, Chrustach, Rawie Mazowieckiej, Głownie, Domaniewicach, Radziejowicach, Boczkach Chełmońskich, Żyrardowie czy Głogowcu. Natomiast poza granicami to: Jerozolima i Dokszyce na Białorusi. Wreszcie na terenie Polski to m.in.: Wejherowo, Zakopane, Warszawa - Choszczówka, Pleszew, Jasna Góra, Ostrów koło Celestynowa, Inowrocław, Bydgoszcz, Warszawa.

Uderza wielkie bogactwo miejsc i okoliczności przepowiadania, m.in. rocznice kościelne i świeckie, święcenia diakonatu i prezbiteratu, wydarzenia kalendarza liturgicznego (np. Środa Popielcowa, Msza św. Krzyżma, Rezurekcja, Wszystkich Świętych), konsekracja dziewicy i wdów, śluby zakonne, pielgrzymki, okoliczności świeckie. W głoszonym słowie wielokrotnie autor nawiązuje do tych elementów. Zresztą, wydaje się, że ma on widoczne zamiłowanie do historii, co wybrzmiewa dość interesująco. Wskazuje także na elementy architektury i wystrój świątyni. To jest ważne sytuowanie przepowiadania w danych miejscu i czasie ze świadomością dynamiki dziejów Zbawienia, które mają swoje konkretne posadowienie. Zatem wydaje się całkowicie słuszne i bardzo przydatne w prezentowaniu zbioru sięganie do przeszłości, tj. wydarzeń, ludzi czy czasowego ich umiejscowienia.

Biskup łowicki nie odwołuje się do przykładów. Jeśli to czasem do konkretnych postaci, zazwyczaj historycznych. Natomiast uderzające jest wielkie bogactwo odniesień do Pisma Świętego, i to obu Testamentów. Wynika to z częstego sięgania do proklamowanych czytań, także psalmu responsoryjnego czy śpiewu przed Ewangelią. Często to wręcz zaskakująca mozaika zestawionych tekstów, która tworzy interesujące obrazy zwiastowanego Bożego słowa.

Prezentowana książka jest bardzo świeża i dynamiczna w proponowanych przemyśleniach homiletycznych. Autor często stawia bardzo oryginalne połączenia tekstów biblijnych i proponuje ich ciekawą interpretację. Mimo że nie jest biblistą, to jednak czuje się wyjątkowo swobodnie wobec proklamowanego słowa. Zawsze są to myśli zgodne 
z nauczaniem Kościoła i stanowią jego bardzo praktyczne przybliżenie, które ma wiele aplikacji do realiów życia konkretnych słuchaczy.

Cennym zabiegiem jest podział tekstów na mniejsze fragmenty wraz z nadaniem im odpowiednich tytułów. W tym względzie czasem moga jawić się pytania. Niemniej ułatwiają one lekturę i pozwalają łatwiej poznać narrację opublikowanych tekstów. Świadczy to także o pewnej systematyzacji wewnętrznej głoszonej homilii.

Na kartach omawianego zbioru wyraźnie wybrzmiewa teolog moralista. Czyni to z homilii cenne propozycje przystające do zwyczajnego życia aktualnych słuchaczy. Autor często proponuje pewne wyznaczniki chrześcijańskiej moralności, wywodząc je oczywiście z czytanego słowa Bożego. Zawsze jednak umieszcza je w konkretnym środowisku wiary i Bożej łaski, spełnianych i doświadczanych we wspólnocie Kościoła.

Łowicki biskup często odwołuje się do lokalnych tradycji, zwłaszcza związanych z Księstwem Łowickim. Jest to wielka tradycja związana z Prymasami Polski, którzy rezydowali przez wiele wieków m.in. w Łowiczu, Skierniewicach, Nieborowie czy Łyszkowicach. Ta tradycja jest nadal bardzo żywa i oddziałuje na współczesną kulturę oraz zwyczaje i tradycję. To właśnie dumni księżacy.

Trzeba jednak pamiętać, że to jest odwieczna tradycja łęczycka, sochaczewska czy rawska, a z nowszych dziejów kutnowska czy żyrardowska. Te elementy wybrzmiewają w przepowiadaniu bp. Andrzeja F. Dziuby. Co więcej, autor umiejętnie stara się je łączyć, oddając ich specyfikę oraz koloryt.

Wielkie tradycje są mocno osadzone w chrześcijaństwie. To z niego wyrosły i w drodze dziejowego rozwoju nadały mu swoje własne specyfikacje. Homilie bp. Andrzeja F. Dziuby starają się rozeznać tę dynamikę kulturową i uczynić ją twórczym narzędziem ku przyszłości. A więc nova et vetera mają szanse twórczego spotkania.

W zaproponowanym zbiorze pasterskiej posługi z lat 2013-2014 wybrzmiewa wiele aktualnych problemów, tak Kościoła jak i ludzi oraz świata. Zatem autor jest twórczo wrażliwy na owo hic et nunc. Jednak nie uprawia on polityki, jakkolwiek by ją określać czy definiować. Jest to bowiem przepowiadanie ewangelizacyjne, z takimi treściami, metodami oraz narzędziami przekazu. Ewangelizacja, i to jeszcze w obrazie nowej ewangelizacji, zadanej Kościołowi przez św. Jana Pawła II, jest wiodącym wyrazem posługi słowa prezentowanego autora.

Autor omawianego zbioru jest bardzo mocno uwrażliwiony Bożym spoglądaniem ku przyszłości. Tchnie w jego homiliach ewangeliczny optymizm. Nie ma tam negatywizmu i dramatu ludzkiej kondycji, także tej związanej z grzechem. Autor zdecydowanie stawia na Boże 
miłosierdzie i w nim upatruje prawdę jedynego Boga, jak to subtelnie określa w tytule swojej kolejnej książki kaznodziejskiej.

Warto w tym kontekście zauważyć, że autor opublikował już ze swego przepowiadania następujące tomiki: Jedynemu Bogu. Z nauczania pasterskiego 2004-2006 (Warszawa 2007), Samemu Bogu. Z nauczania pasterskiego 2007-2008 (Sandomierz 2009), Tylko Bogu (Warszawa 2011), Bogu samemu. Z nauczania pasterskiego 2011-2012 (Warszawa 2013). Dają one pewien obraz wskazywanego przepowiadania już w dłuższym odcinku czasu. Łatwo można zauważyć, iż autor jest konsekwentny w swej posłudze słowa.

Biskup Andrzej F. Dziuba prezentuje się bardzo twórczo w proponowanym słowie Bożym. To głoszenie w porę i nie w porę (por. $2 \mathrm{Tm} \mathrm{4,12),}$ świadczą o tym jego szerokie okoliczności. Nie zauważa się powtórzeń, co świadczy o autentyzmie przepowiadania. Widać, że nie są to teksty czytane, ale żywa mowa, stąd ma ona swoją specyfikę kaznodziejską. Nadaje to jej wartkości oraz żywotności. 